\title{
Effect of dietary supplementation of neem oil (Azadirachtaindica) on the growth performance and nutrient digestibility of weaned rabbits
}

\author{
Oluwafemi R. A, \\ Oluwayinka E. O \\ Alagbe J. $O$ \\ Department of Animal Science, Faculty of Agricultural Sciences, University of Abuja, \\ FCT-Abuja. Nigeria. \\ Corresponding author: E-mail: olaoluwayinkamail@gmail.com; +2347037755734
}

\begin{abstract}
The objective of the present study was to determine the effect of dietary supplementation of neem oil (Azadirachtaindica) on the growth performance and nutrient digestibility of weaned rabbits. A total of 50 weaned male cross bred rabbits between 5-6 weeks with an average weight of 565.4g-566.8gwere divided into five dietary groups of ten (10) weaned rabbits each in a completely randomized design. The dietary treatments include a control, T1 (basal) diet with no neem oil (NOL), T2, T3, T4 and T5 were fed basal diet supplemented with NOL at $0.1 \%, 0.2 \%, 0.3 \%$ and $0.4 \%$ respectively. Feed and water were offered ad libitum throughout the experiment which lasted for 12 weeks. The data obtained was used to evaluate the growth performance: weight gain (WG), feed intake (FI), feed conversion ratio (FCR), mortality and nutrient digestibility (dry matter, crude protein, crude fibre and ether extract). WG, ADFI, TFI were significantly $(P<0.05)$ different among the treatments. T5 had the highest weight gain $(755.90$ g) followed by T4(734.0g), T3(705.90g), T2(705.0g) and T1(621.80g) respectively. Highest mortality was recorded in $T 1$ (2\%) followed by T2 (1\%), none was recorded in T3, T4 and T5. Neem oil significantly influenced $(P<0.05)$ all the parameters measured. It could be concluded thatneem oil contains some essential nutrients and bioactive chemicals and could be supplemented in the diet of rabbit at $0.4 \%$ without any deleterious effect on the general performance of the animal.
\end{abstract}

Key words: Rabbits, neem seeds, Azadirachta indica, performance, nutrients.

\section{INTRODUCTION}

With so many research carried out to find endogenous feed alternatives for rabbit production as the high cost of raw materials that are used for commercial feed increase the production cost., there is also an urgent need to embark on scientific findings on livestock's natural growth promoter which will ensure increasing growth rate, enormous availability of meat and other high value bye-products for the entire populace at relatively conservative cost. Producers use growth promoters to increase growth rates and improve overall efficiency and product quality without leaving any toxic residue in the body system of livestock. Their inclusion in feedstuffs should be designed so as to feature a pharmacological characteristic that enhance the immunity of the animal and to help in minimizing the use of the conventional antibiotics in prevention and treatment of diseases of livestock. The conventional artificial growth promoters are known to have deleterious effect on human who are the secondary consumer of residues of artificial growth promoter in the body of livestock (Sinniah, 1981).

Neem belongs to the kingdom: Plantae; Division: Magnoliophyta; Order: Sapindales; Family: Meliaceae; Genus: Azadirachta; Species: indica., It is a tropical evergreen related to mahogany. Native to east India and Burma, it grows in much of Southeast Asia and West Africa; a few trees have recently been planted in the Caribbean and several Central American countries, including México. The name Azadirachtaindicais derived from a Persian term "Axaddarakth" (free tree). In Ayurveda it is known as the "Arishta', which means "relieving sickness" in Sanskrit. It is a medium sized or large evergreen tree with irregular rounded crown, attaining a height of $14 \mathrm{~m}-20 \mathrm{~m}$. It is a hardy tree that grows well in sandy, stony shallow soil, and is tolerant to alkaline, saline and acidic soil and it grows well on black cotton soil (Patnaik, 1993).

Neem is ubiquitous in Northern Nigeria. The Neem tree popularly referred to in Hausa language as Dogonyaro is a tree in the mahogany family with broad dark brown stem and widely spread branches. According to Subbalakshmi et al., (2012), all parts of neem like seeds, flowers, bark and leaves are beneficial due to their medicinal properties. Research has shown that neem will boost the immune system by stimulating the production of T-cells when challenged with infections (Upadhyay, 1990). The role of medicinal plants in disease prevention or control has been attributed to antioxidant properties of their constituents, usually associated to a wide range of amphipathic molecules, broadly termed polyphenolic compounds (Demirayet al., 2009). The bark of the neem has been reported to have higher phenolic and antioxidant activity compared to the leaf (Ghimeray et al., 2009; Olabinri et al., 2009). Neem oil, bark 
and leaf extracts have been therapeutically used as folk medicine to control diseases like leprosy, intestinal helminthiasis, respiratory disorders, constipation and skin infections (Biswas et al., 2002). The neem tree contains more than 100 bioactive ingredients and the most important bioactive compound is azadirachtin (Nahak and Sahu, 2010). The Neem leaves, neem oil and de-oiled neem seed cake are used as animal feeds (Ogbuewuet al., 2010a). The neem leaves contain appreciable amounts of proteins, minerals, carotene and adequate amount of trace minerals (Ogbuewuet al., 2010). Neem tree as one of the most researched tree in the world has attracted world-wide prominence due to its vast range of medicinal propertieslike antibacterial, antiviral, antifungal, antiprotozoal, hepatoprotective and other various properties without showing any adverse effect (Kale et al., 2003).

The compounds in neem have been divided into two major classes; isoprenoids and others (Singh et al., 1996). The isoprenoids include diterpenoids and triterpenoids containing protomeliacins, limonoids, azadirone and its derivatives, gedunin and its derivatives, vilasinin type of compounds and Csecomeliacins such as nimbin, salanin and azadirachtin. The none-isoprenoids include proteins (amino acids) and carbohydrates (polysaccharides), sulphurous compounds, polyphenolics such as flavonoids and their glycosides, dihydrochalcone, coumarin and tannins, aliphatic compounds and several fatty acids (dodecanoic, tetradecanoic, elcosanic, etc). (Zengin et al., 2016a, Zengin et al., 2016b).

\section{Experimental Site}

\section{MATERIALS AND METHODS}

The study was carried out at University of Abuja Teaching and Research farm, Airport road, Abuja., in Gwagwalada area council of the Federal Capital Territory, Abuja. Gwagwalada is situated in the North central zone of Nigeria., Lying at the latitude N 9.0765 and longitude E 7.3986 at an average elevation of $476 \mathrm{~m}$ above sea level.

\section{Collection and processing of neem oil (NOL)}

Neem seeds were collected from Gwagwalada, Abuja and identified at the department of biological sciences, University of Abuja, Nigeria. The seeds of Neem were separated from the seed coats manually and sundried for 2 weeks. The dried seeds were granulated into coarse particles using a blender (Model Ap-DKL, Samsung). Oil was extracted using the soxhlet extraction method; it was later poured into a well labeled container for further analysis.

\section{Experimental animals and their management}

Fifty (50) apparently healthy, cross bred weaned male rabbits with average initial body weight of $565.4 \mathrm{~g}-566.8 \mathrm{~g}$ were used for the study and were randomly allotted into Five Treatments with ten (10) rabbits per treatment designated as treatment 1, 2, 3, 4 and 5 in a Completely Randomized Design (CRD), animals were kept in an all wired hutch measuring $35 \times 35 \times 55 \mathrm{~cm}$ (width $\times$ length $\times$ height).All treatments have 5 replicates with two (2) rabbits per replicate. After 14 days of acclimatization, all rabbits were fed diets corresponding to their treatments and given prophylactic treatment with broad-spectrum medication (Kepromec ${ }^{\circledR}$ ) against endoparasites and helminthes infestation before the commencement of the experiment. Feed and water was given ad libitum and all other management practices were strictly adhered to.

\section{Experimental diets}

Basal were formulated to meet the nutritional requirement for rabbits according to NRC (1977).

Treatment 1 - Basal diet $+0 \%$ NOL

Treatment 2 - Basal diet $+0.1 \%$ NOL

Treatment 3 - Basal diet $+0.2 \%$ NOL

Treatment $4-$ Basal diet $+0.3 \%$ NOL

Treatment 5 - Basal diet $+0.4 \%$ NOL

\section{Measurements}

Daily feed consumption $(\mathrm{g})=$ Amount of feed Supplied-Amount of feed left

Feed conversion ratio $(F C R)=$ Dry Matter Intake $(\mathrm{g}) \times 100$

$$
\text { Live weight gain }
$$

Average daily gain $(\mathrm{ADG})=\underline{\text { Final body weight }- \text { Initial body weight }}$

Total days of the experiment

\section{Digestibility trial}

At the last week of the experiments, fifteen (15) rabbits (3 per treatment) were randomly selected and were housed individually in metabolic cages which allow separation of faeces and urine. Each cage was provided with manual feeder and drinker. The digestibility study lasted seven days, average feed consumption 48.60 - 49.04g was accurately determined during the whole experiment period and faeces were collected for seven days as a collection period (Perez et al., 1995)., the collection was performed at approximately 09:00h each morning before the next daily ration was provided. The rabbits are fed 
measured amounts of feed and the left over feed and faeces voided are carefully measured .5\% of faeces voided were dried at $80^{\circ} \mathrm{C}$ in an oven for 24 hours. The dried faecal samples were stored in air-tight container for chemical analysis. This can be represented using the equation;

$$
\text { Digestibility }(\%)=\frac{\mathrm{C}_{\text {feed }}-\mathrm{C}_{\text {faeces }}}{\mathrm{C}_{\text {feed }}} \times 100
$$

Where $\mathrm{C}_{\text {feed }}$ and $\mathrm{C}_{\text {faeces }}$ refer to the amount of feed eaten and faecal excreted respectively. (1990).

The proximate composition of the diets and faecal samples were determined according to AOAC

\section{STATISTICAL ANALYSIS}

All data were subjected to one -way analysis of variance (ANOVA) using SPSS (18.0) and significant means were separated using Duncan multiple range tests (Duncan, 1955). Significant was declared if $\mathrm{P} \leq 0.05$.

\section{RESULTS AND DISCUSSION}

\section{Proximate composition of experimental diet}

Table 1 shows the proximate composition of experimental diet. The proximate components contained crude protein $(18.22 \%)$, crude fibre $(13.22 \%)$, ether extract $(3.20 \%)$, ash $(6.15 \%)$ and energy $(2566.5 \mathrm{kcal} / \mathrm{kg})$. The crude protein, crude fibre and energy values reported in this experiment is in agreement with the findings of Ahmed et al. (2018); Alagbe and Oluwafemi (2019) but contrary to the reports ofAhmed et al. (2019) when thyme oil was fed to growing rabbits. However, all values were within the nutritional requirement of growing rabbits according to NRC (1977). Adequate intake of dietary fibre lowers the serum cholesterol level, risk of coronary heart disease, constipation and colon and breast cancer (Fashola, 2011; Alagbe, 2019; Olanipekun et al., 2016). Ash content gives an indication of the amount of minerals present in a feed, which are important in many biochemical reactions functioning as co-enzyme and aid physiological functioning of the major metabolic processes in the body (Ojewuyi et al., 2014).

Table1: Chemical composition of experimental diet

\begin{tabular}{ll}
\hline Materials & Quantity $(\mathrm{Kg})$ \\
\hline Maize & 30.0 \\
Wheat offal & 20.0 \\
Soya meal & 16.25 \\
Groundnut cake & 10.0 \\
Palm kernel meal & 20.0 \\
Bone meal & 2.00 \\
Limestone & 1.00 \\
Lysine & 0.01 \\
Methionine & 0.01 \\
*Premix & 0.25 \\
Salt & 0.25 \\
Total & 100.0 \\
Calculated analysis & \\
Crude protein $(\%)$ & 17.22 \\
Crude fibre $(\%)$ & 13.20 \\
Ether extract $(\%)$ & 3.02 \\
Ash $(\%)$ & 6.15 \\
Energy (Kcal/kg) & 2566.5 \\
\hline
\end{tabular}

*Premix supplied per kg diet: Vit A, 7,000 I.U; Vit E, 5mg; Vit D3, 3000I.U, Vit K, 3mg; Vit B2, 5.5mg; Niacin, 25mg; Vit B12, 16mg; Choline chloride, 120mg; Mn, 5.2mg; Zn, 25mg; Cu,

2.6g; Folic acid, 2mg; Fe, 5g; Pantothenic acid, 10mg; Biotin, 30.5g; Antioxidant, 56mg. 


\section{rabbits \\ Effect of different levels of neem (Azadirachtaindica) oil on the performance of weaned}

Table 2 revealed the performance characteristics of weaned rabbits graded level of neem oil. Initial body weight (IBW), final body weight (FBW), weight gain (WG), average daily weight gain (ADWG), average weekly weight gain (AWWG) and total feed intake (TFI) ranged between $566.20-566.80 \mathrm{~g}$, $1188.40-1322.10 \mathrm{~g}, 6.21-755.9 \mathrm{~g}, 8.88-10.80 \mathrm{~g}, 62.18-75.60 \mathrm{~g}$ and $2900.1-3433.1 \mathrm{~g}$ respectively. All the values were higher in T4 and T5, intermediate in T2 and T3 and lowest in T1 $(\mathrm{P}<0.05)$. FCR value ranged between $4.50-5.50$ and it was significantly different among the treatments $(\mathrm{P}<0.05)$. Mortality were recorded in $\mathrm{T} 1$ and $\mathrm{T} 2(\mathrm{P}<0.05)$, none were recorded in the other treatments. The higher weight gains in T4 and T5 could be attributed to the presence of bioactive chemicals or phytochemicals in neem oil. According to Oluwafemi et al. (2020) phytochemicals performs multiple biological activities such as anti-inflammatory (Hyun et al., 2018; Alagbe et al., 2020), antibacterial (Tomoriet al., 2007), antioxidant (Manita and Gaurav, 2020), immunostimulatory (Kavitaet al., 2014), antifungal, hepatoprotective and cardiovascular effects (Joy et al., 2019; Olafadehan et al., 2020), antiviral (Olafadehan et al., 2020). Bioactive chemicals include: tannins, saponins, flavonoids, alkaloids, phenols, terpenoids etc. The supplementation of neem oil in the diet of the animals promotes eubiosis, thus enhancing the activities of beneficial bacteria (lactobacilli) and lowering pathogenic bacteria(Alagbe et al., 2020). This result is in agreement with the findings of Ikyumeet al. (2019); Cardinal et al. (2007); Castellini et al. (2007);Abd El-Hadyet al. (2013)but contrary to the reports of Eibenet al. (2008); Musa et al. (2020) on feed additives as they affect the fattening performance of rabbits. Mortality was not recorded in T3, T4 and T5; this could be possibly attributed to the presence of phenols, saponins and tannins. According to Hollman (2001), phenols are strong antioxidants capable of scavenging free radicals. Tannins possess antibacterial and antiviral activities (Adisa et al., 2010; Enzo, 2007) while saponins have been suggested to be involved in antimicrobial and anti-inflammatory activities (Cheeke 2000; Alagbe et al., 2019; Akintayo and Alagbe, 2020).

Table 2: Effect of different levels of neem (Azadirachtaindica) oil on the performance of weaned rabbits

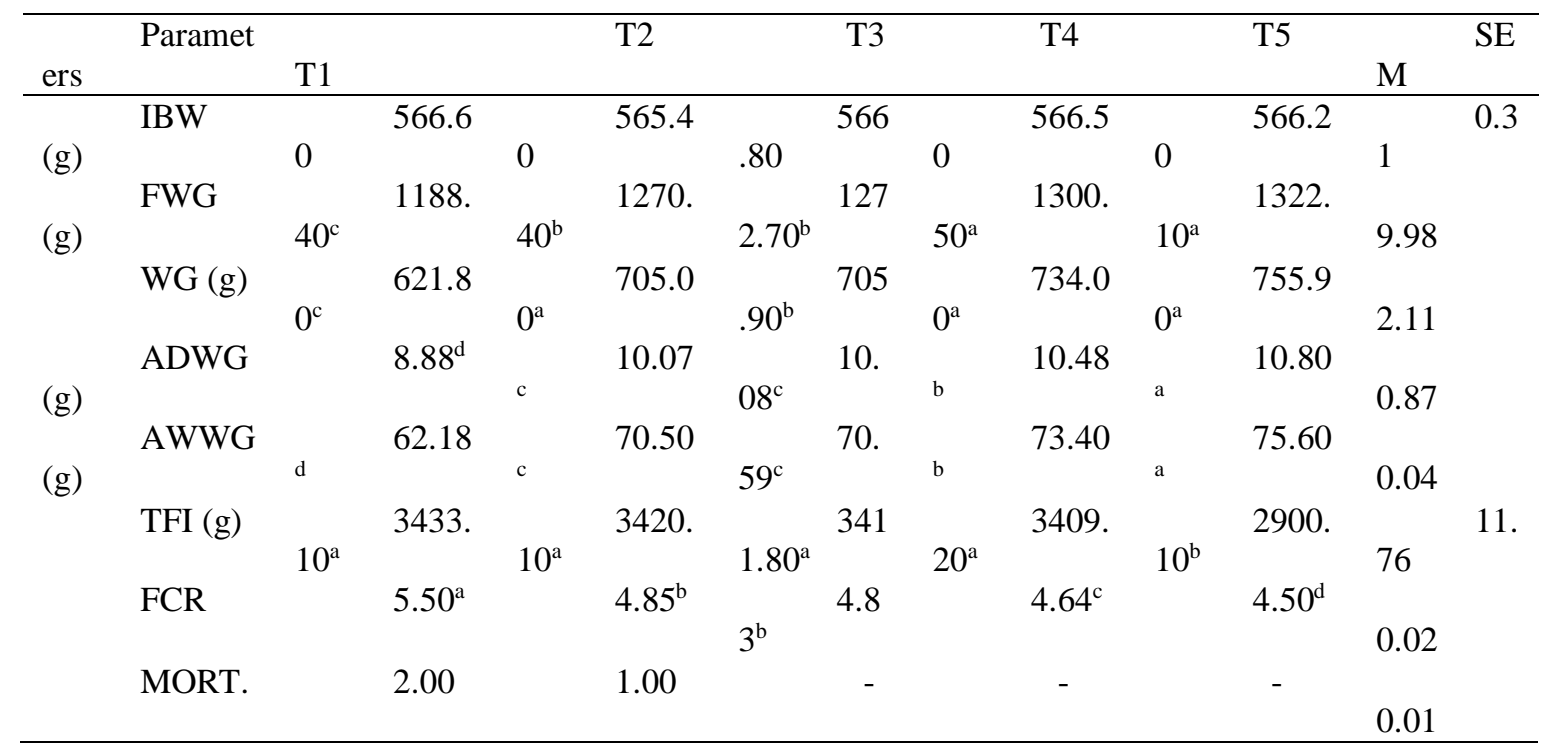

Means in the same row with different superscripts differ significantly $(P<0.05)$

Initial body weight (IBW); final body weight (FBW); weight gain (WG); average daily weight gain $(\mathrm{ADWG})$; average weekly weight gain (AWWG) and total feed intake (TFI) 
Nutrient digestibility of rabbits fed graded levels of neem oil

Nutrient digestibility of rabbits fed graded levels of neem oil is presented in Table 3. Dry matter, crude protein, crude fibre and ether extract digestibility ranged between $75.11-89.30 \%, 60.22-78.90$ $\%, 50.92-69.31 \%$ and $67.89-70.47 \%$ respectively. There was a significant difference in the parameters measured $(\mathrm{P}<0.05)$. This result is in agreement with the findings of Omokore and Alagbe (2019); Bassionyet al. (2015); Bölükbaşi et al. (2006); Çabuket al. (2003); Gaafaret al. (2014); Shittu et al. (2020) when pumpkin (Cuncurbitamoschata) and black seed (Nigella sativa) oils were supplemented in the diets of rabbits but contrary to the reports of Taiwo et al. (2005); Oso et al. (2006) when weaned rabbits were fed rice millings waste based diets. Bioactive chemicals in neem oil ensure proper absorption of nutrient among animals in T4 and T5, thus ensuring better feed conversion among animals.

Table 3: Nutrient digestibility of rabbits fed graded levels of neem oil

\begin{tabular}{|c|c|c|c|c|c|c|c|c|c|c|c|c|}
\hline Parame & & & & & & T3 & & $\mathrm{T} 4$ & & & & SE \\
\hline $\operatorname{ers}(\%)$ & $\mathrm{T} 1$ & & $\mathrm{~T} 2$ & & & & & & T5 & & M & \\
\hline Dry & & 75 . & & 79.2 & & 80.93 & & 85.3 & & 89.30 & & 2.7 \\
\hline matter & $11^{\mathrm{c}}$ & & $1^{\mathrm{b}}$ & & $\mathrm{b}$ & & $3^{\mathrm{a}}$ & & $\mathrm{a}$ & & 1 & \\
\hline $\begin{array}{l}\text { Crude } \\
\text { protein }\end{array}$ & $22^{c}$ & 60. & $7^{\mathrm{b}}$ & 65.9 & $\mathrm{~b}$ & 69.03 & $1^{\mathrm{a}}$ & 71.4 & $\mathrm{a}$ & 78.90 & 1.98 & \\
\hline fibre & $92^{\mathrm{b}}$ & 50. & $0^{\mathrm{b}}$ & 57.9 & a & 61.88 & $1^{\mathrm{a}}$ & 68.8 & $\mathrm{a}$ & 69.31 & 1.02 & \\
\hline $\begin{array}{l}\text { Ether } \\
\text { extract }\end{array}$ & $89^{\mathrm{b}}$ & 67. & $0^{\mathrm{b}}$ & 61.8 & $\mathrm{a}$ & 67.98 & $1^{\mathrm{a}}$ & 69.4 & a & 70.47 & 2.33 & \\
\hline
\end{tabular}

Means in the same row with different superscripts differ significantly $(P<0.05)$

\section{CONCLUSION}

Bioactive chemicals in neem oil which may have acted singly or in synergy with one another ensure proper absorption of nutrients among animals in T4 and T5, thus ensuring better feed conversion among animals.A. indicain diets of growing rabbits had a positive effect on growth performance, feed conversion ratio and on mortality rate.

\section{REFERENCES}

1. Abd El-Hady, A.M., O. A.H. El-Ghalid and A.M. EL-Raffa. (2013). Influence of a herbal feed additives (digestarom $\AA$ ) on productive performance and blood constituents of growing rabbits. Egyptian J. Anim. Prod. (2013) 50(1):27-37.

2. A.O.A.C. (2000). Association of Official Analytical Chemists. Official Methods of Analysis 19th Edition Washington, D.C Pages 69-77.

3. Akintayo Balogun Omolere. M and Alagbe, J.O (2020). Probiotics and medicinal plants in poultry nutrition: A review. United International Journal for Research and Technology, 2(1): 7-13.

4. Alagbe, J.O., Agubosi, O.C.P., Ajagbe, A.D, Shittu, M.D and Akintayo Balogun, O.M (2020). Performance, haematology and serum biochemical parameters of growing grass cutters fed Phyllantus amarus and Piliostigma thonningii leaf meal mixture as partial replacement for Soya bean meal. United International Journal for Research and Technology, 2(1): 14-23.

5. Ahmed A.A. Abdel-Waret ,Eman M.M. Taha, Karl-Heinz Südekun, Jayant Lohakare (2018). Thyme oil inclusion levels in a rabbit ration: Evaluation of productive performance, carcass criteria and meat quality under hot environmental conditions. Animal Nutrition 4 (2018) 410e416

6. Ahmed E. Abd El-Azeem, Adham A. Al-Sagheer, A.H. Daader and S.M. Bassiony. (2019). Effect of dietary supplementation with betaine, thyme oil and their mixtures on productive performance of growing rabbits. Zagazig J. Agric. Res., 46(3): 816-827.

7. Alagbe, J.O and Oluwafemi, R.A. (2019). Growth performance of weaner rabbits fed Noni (Morinda citrifolia) and Moringa olifera leaf mixture as partial replacement of soya bean meal. International Journal of Advanced Biological and Biomedical Research. 7(2): 185-195.

8. Alagbe, J.O (2019). Proximate, mineral and phytochemical analysis of Piliostigma thonningii stems bark and roots. International Journal of Biological, Physical and Chemical Studies, 1(1): 1-7.

9. Alagbe, J.O (2020). Caecal Microbial Population of Growing Grass Cutters (Thyronoyms Swinderianus) Fed Phyllantus Amarus and Pilogstigma Thonngii Leaf Meal Mixture as Partial Replacement for Soya Bean Meal. Concept of Dairy and Veterinary Sciences. 3(5): 350 - 355.

10. Alagbe, J.O., Shittu, M.D and Eunice Abidemi Ojo (2020). Prospect of leaf extracts on the performance and blood profile of monogastric - A review. International Journal of Integrated Education. 3(7): 122-127. 
11. Bassiony, S., M.M. Elhindawy, AE. Attia and I.E. Ismail (2015). Effect of some bioactive components of essential oils on growing rabbits' performance. Zagazig J. Agric. Res., 42 (5):11711182.

12. Biswas K., Chattopadhyay I., Banerjee R. K., Bandyopadhyay U. (2002). Biological activities and medicinal properties of Neem (Azadirachtaindica) Current Science.82(11):1336-1345.

13. Bölükbaşi, S.C., M.K. Erhan and A. Özkan (2006). Effect of dietary thyme oil and vitamin E on growth, lipid oxidation, meat fatty acid composition and serum lipoproteins of broilers. S. Afr. J. Anim. Sci., 36: 189-196.

14. Çabuk, M., A. Alçiçek, M. Bozkurt and N. Imre (2003). Antimicrobial properties of the essential oils isolated from aromatic plants and using possibility as alternative feed additives. II. Nat. Anim. Nut. Con., 18 (20): $184-187$.

15. Castellini C., Cardinali R., Rebollar P.G., Dal Bosco A., Jimeno V., Cossu M.E. 2007. Feeding fresh chicory (Chicoriaintybus) to young rabbits: Performance, development of gastro-intestinal tract and imune functions of appendix and Peyer's patch. Anim. Feed Sci. Technol., 134, 56-65.

16. Cardinali R., Dal Bosco A., Mourvaki E., Moscati L., Scicutella N., Battistacci L., Castellini C. 2007a. Effect of dietary microencapsulated organic and inorganic acids and essential oils on serum innate and caecal fermentation. In: Proc. Giornate di Coniglicoltura ASIC 2007, September, Forlí, Italy, 133.

17. Demiray S., Pintado M. E. and Castro P.M.L., (2009) Evaluation of phenolic profiles and antioxidant activities of Turkish medicinal plants: Tiliaargentea, Crataegi folium leaves and Polygonumbistoa roots. World Acad. Science England. Technol., 54:312-317.

18. Eiben, C., Gippert, T., Gódor-SurmannK andKustos, K. (2008). Feed additives as they affect the fattening performance of rabbits. Nutrition and Digestive Physiology. 9th World Rabbit Congress June 10-13, 2008 - Verona - Italy

19. Gaafar HMA, Ragab AA, El-Reidy KFA (2014) Effect of diet supplemented with pumpkin (Cuncurbitamoschata) and black seed (Nigella sativa) oils on performance of rabbits. In: Growth performance, blood haematology and carcass traits of growing rabbits. Reports and Opinions., volume 16: $52-59$.

20. Ghimeray A. K., Jin C. W., Ghimire B. K., Cho D. H. (2009). Antioxidant activity and quantitative estimation of azadirachtin and nimbin in AzadirachtaindicaA. Juss grown in foothills of Nepal African Journal of Biotechnology. 8(13):3084-3091.

21. Ikyume, T.T., Ogu I.E, Okwori IA, Shaahu DT. (2019). Growth Performance and Apparent Nutrient Digestibility of Grower Rabbits Fed Combinations of Concentrate with Grass and/or Legume Forage. Journal of Multidisciplinary Research and Reviews. 1(1): 41-45.

22. Gaafar HMA, Ragab AA, El-Reidy KFA (2014) Effect of diet supplemented with pumpkin (Cuncurbitamoschata) and black seed (Nigella sativa) oils on performance of rabbits. In: Growth performance, blood haematology and carcass traits of growing rabbits. Reports and Opinions, volume 16: 52-59.

23. Shittu, M.D., Adejumo, D.O., Ewuola, E.O., Alaba, O., Alagbe, J.O and Ojebiyi, O.O. (2020). Gut morphometric characteristic and ecological response of broiler starter fed varied levels of protein. Asian Journal of Animal Science, 14(1):33-39

24. Ghimeray A. K., Jin C. W., Ghimire B. K., Cho D. H. (2009). Antioxidant activity and quantitative estimation of azadirachtin and nimbin in AzadirachtaindicaA. Juss grown in foothills of Nepal African Journal of Biotechnology. 8(13):3084-3091.

25. Ikyume, T.T., Ogu I.E, Okwori IA, Shaahu DT. (2019). Growth Performance and Apparent Nutrient Digestibility of Grower Rabbits Fed Combinations of Concentrate with Grass and/or Legume Forage. Journal of Multidisciplinary Research and Reviews. 1(1): 41-45.

26. Kale, B.P., M.A. Kothekar, H.P. Tayade, J.B. Jaju and M. Mateenuddin. (2003). Effect of aqueous extract of Azadirachtaindica leaves on hepatotoxicity induced byantitubercular drugsin rats. Indian J. Pharmacol.,35: 177-180. 
27. Musa, Bashir., Alagbe, J.O., Adegbite Motunrade Betty, Omokore, E.A. (2020). Growth performance, caeca microbial population and immune response of broiler chicks fed aqueous extract of Balanites aegyptiaca and Alchornea cordifolia stem bark mixture. United Journal for Research and Technology, 2(2):13-21.

28. Nahak G., Sahu R. K. (2011). Evaluation of antioxidant activity of flower and seed oil of Azadirachtaindica A. juss. Journal of Applied and Natural Science.3(1):78-81.

29. Ogbuewu, I.P., Odoemelam, V.U., Obikaonu, H.O., Opara, M.N., Emenalom, O.O., Uchegbu, M.C., Okoli, I.C., Esonu, B.O. and Iloeje, M.U. (2010a). The growing importance of neem (Azadirachtaindica A. Juss) in agriculture, industry, medicine and environment: A Review. Research Journal of Medicinal Plants, 3(2): 1-27.

30. Ogbuewu, I.P., Okoli, I.C. and Iloeje, M.U. (2010b). Assessment of blood chemistry, weight gain and linear body measurements of pre-puberal buck rabbits fed different levels of Neem (Azadirachtaindica A. Juss.) leaf meals. Chilean Journal of Agricultural Research, 70(3): 515520.

31. Olabinri, B.M., J.A. Adebisi, O.F. Odesomi, P.F. Olabinri and G.E. Adeleke (2009). Experimentalclassification of the antioxidant capacity of the leaf, stem and root barks of MagniferaindicaandAzadirachtaindica.Afr. J. Biotechnol., 8(13): 2968-2972.

32. Olafadehan, O.A., Oluwafemi, R.A and Alagbe, J.O. (2020). Performance, haemato-biochemical parameters of broiler chicks administered Rolfe (Danielliaoliveri) leaf extract as an antibiotic alternative. Advances in Research and Reviews, 2020, 1:4.

33. Olafadehan, O.A., Oluwafemi, R.A and Alagbe, J.O (2020). Carcass quality, nutrient retention and caeca microbial population of broiler chicks administered Rolfe (Danielliaoliveri) leaf extract as an antibiotic alternative. Journal of Drug Discovery. 14(33):146-154.

34. Oluwafemi, R.A., Isiaka Olawale and Alagbe, J.O. (2020). Recent trends in the utilization of medicinal plants as growth promoters in poultry nutrition- A review. Research in: Agricultural and Veterinary Sciences. 4(1): 5-11

35. Oso A.O, Bamgbose AM, Isah OA, Olatunji JEN, Mabadeje AT, Alade AA, Oni AO (2006) Performance of weaner rabbits fed rice millings waste based diets. Journal of Animal and Veterinary Advances 5: 836-838.

36. Omokore, E.O and Alagbe, J.O. (2019). Efficacy of dried Phyllantus amarus leaf meal as an herbal feed additive on the growth performance, haematology and serum biochemistry of growing rabbits. International Journal of Academic Research and Development. 4(3): 97-104.

37. Ojewuyi, O.B, Ajiboye, T. O, Adebanjo, E. O, Balogun, A, Mohammed, A.O (2014). Proximate composition, phytochemical and mineral contents of young and mature Polyalthia longifolia Sonn.leaves Fountain Journal of Natural and Applied Sciences: 2014; 3(1): 10 - 19.

38. Patnaik, N. (1993). Garden of life: An introduction to the healing plants of India. Doubleday, New York pp. $40-42$.

39. Duncan, D.B. (1955). Multiple range and multiple F-test. Biometrics 11(1):1-42.

40. National Research Council (1977). Nutrient requirement of rabbits $9^{\text {th }}$ Rev Edn, Washington D.C. National Academy Press.

41. Subbalkshmi L., Muthukrishnan P., Jeyaraman S. (2012). Neem products and their Agricultural application.

42. Taiwo A.A, Adejuyigbe AD, Adebowale EA, Oshotan JS, David OO (2005) Performance and nutrient digestibility of weaned rabbits fed forages supplemented with concentrates. Nigerian Journal of Animal Production. 32:74-78

43. Upadhyay, C. (1990). The medicinal properties of Neem (Azadirachtaindica) tree. In: Animal Pharmacology. Second Edition Longman England. 
44. Zengin, G., Ceylan, R. O., Guler, G., Carradori, S., Uysal, S., Aktumsek, A. (2016a). Enzyme inhibitory effect and antioxidant properties of Astragaluslagurusextract. Current enzyme inhibition 12, 177-182.

45. Zengin, G., Locatell, M., Carradori, S., Mocan, A. M., Aktumek, A., (2016b). Total phenolics, flevonoids, condensed tannins content of eight Centaurea species and their broad inhibitory activities against cholinesterase, tyrosinase, $\alpha$-amylase and $\alpha$-glucosidase. Notulae Botanic HortiAgrobotanici Cluj-Napoca 44, 195-200 